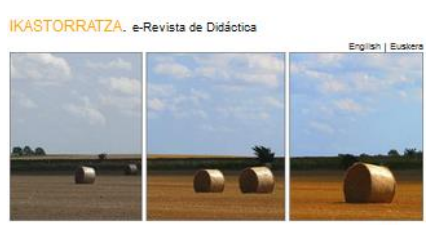

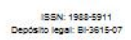

Inicio, Sobre nosotros, Publicaciones|, Participe

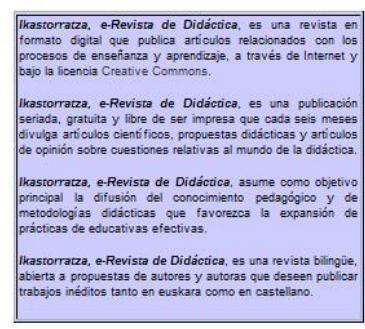

\section{IKASTORRATZA. Didaktikarako e-aldizkaria}

\author{
IKASTORRATZA. e-journal on Didactics
}

\title{
Idazteko zailtasunak detektatzeko eta esku hartzeko proposamena Lehen Hezkuntzan
}

Irune Ibarra

irune.ibarra@ehu.eus

Unai Atutxa

atutxaunai@gmail.com

Mikel Iruskieta

mikel.iruskieta@ehu.eus

To cite this article:

Ibarra, I., Atutxa, U. \& Iruskieta, M. (2021). Idazteko zailtasunak detektatzeko eta esku hartzeko proposamena Lehen Hezkuntzan. IKASTORRATZA. e-Revista de Didáctica, 27, 1-29. DOI: 10.37261/27_alea/1

To link to this article:

https://doi.org/10.37261/27_alea/1

Published online: 30 Sept. 2021 


\title{
Idazteko zailtasunak detektatzeko eta esku hartzeko proposamena Lehen Hezkuntzan
}

\author{
Irune Ibarra1, Unai Atutxa², Mikel Iruskieta $^{2}$ \\ ${ }^{1}$ Hezkuntza, Filosofia eta Antropologia Fakultatea \\ Universidad del País Vasco/Euskal Herriko Unibertsitatea. UPV/EHU \\ irune.ibarra@ehu.eus \\ ${ }^{2}$ HiTZ Basque Center for Language Technologies - Ixa NLP Group \\ Universidad del País Vasco/Euskal Herriko Unibertsitatea. UPV/EHU \\ atutxaunai@gmail.com \\ mikel.iruskieta@ehu.eus
}

\section{Laburpena}

Idazteko zailtasunak hasiera-hasieratik detektatzea eta esku hartzea oso garrantzitsua da ikaslearen ikaskuntza prozesuaren garapenerako, egun eskolako ebaluazio-sistema gehienak idatzizko ekoizpenean oinarritzen direlako. Ikasleen idazteko zailtasunak mota desberdinetakoak izaten dira: neuropsikologikoak eta hizkuntzakoak, besteak beste. Artikulu honen helburua da idazten ikasten ari diren ikasleen idazteko zailtasunak identifikatzeko egiaztapen-zerrenda bat proposatzea eta esku-hartzeko aukerak eskaintzea. Idazteko zailtasunak ikasleen laginen bidez erakusten dira, lagin hauek eskola bateko formakuntza-saioetatik lorturikoak izanik.

\begin{abstract}
Detecting and resolving writing difficulties is of the utmost importance for student success, mostly because school assessment systems are based on written production tasks. Students writing difficulties come from a variety of sources: neurodevelopmental and language source, among others. The aim of this article is to propose a checklist to identify writing difficulties in young students learning to write. Examples and young student productions of writing difficulties are shown. The examples were obtained in a school training session.
\end{abstract}


Hitz-gakoak: Idazketa-zailtasunak, egiaztapen-zerrenda, Lehen Hezkuntza, detekzioa, zailtasun neuropsikologikoak

Key words: Writing difficulties, checklist, Primary School, neuropsychological constrains

\section{Sarrera}

Idazteko zailtasunak hasiera-hasieratik detektatzea eta esku-hartzea oso garrantzitsua da ikaslearen ikaskuntza prozesuaren garapenerako, egun eskolako ebaluazio-sistema gehienak idatzizko ekoizpenean oinarritzen direlako. Beraz, komeni da hasiera-hasieratik idazketa lantzea eta leudekeen arazoak identifikatzea, horiek gainditzeko. Baina idazketaren lanketa ez da erraza; izan ere, idazketa, hizkuntzaren forma altuena bezala deskribatu da: 'writing is often described as the highest form of language' (Levine et al., 1981: 22); horrez gain, konplexua da arazoren bat edo beste antzematea; izan ere, idazketan parte hartzen duten trebeziak eta azpi-trebeziak askotarikoak dira eta idazketa eragozten duten arazoak ere iturri anitzekoak dira (Berninger, 2004).

Garapeneko idazleen idazketa-ezaugarriak hobeto ulertzeko, Berninger eta lankideek ikuspegi kognitiboaren barruan garatu dituzten hiru eredutan oinarrituko gara (Berninger et al., 1991; Berninger eta Swanson, 1994; Berninger, Abbott, Nagy, eta Carlisle, 2010). Honela, Berninger et al.en (1991) eredu teorikoak adierazten duenez, idazketa eragozten duten aldagaiak, hiru motatakoak dira: zailtasun neuropsikologikoak, hizkuntzarekin loturiko zailtasunak eta zailtasun kognitiboak. Gainera, Berningerrek eta Swansonek (1994) proposatutako ereduaren arabera, idazketaren garapenean, testuak idazterakoan hitzarekin harremandutako trebeziak lehenago agertzen dira esaldiarekin harremandutako trebeziak baino, eta esaldi-trebeziak lehenago agertzen dira paragrafo-mailako trebeziak baino. Bestalde, hitz mailan, oztopatuta egon daitezke arlo fonologikoaren, ortografikoaren edota morfologikoaren kodetzea edota prozesatzea.

Idazketa oztopatzen duten mugak Lehen Hezkuntzan (LH) ondo identifikatzea oso garrantzitsua da eta badaude beste hizkuntzetan diagnosi diferentzialak egiteko proba estandarizatuak, aipaturiko eredu kognitibotik sorturikoak. Adibidez, ingelesez, Pal-II Reading and Writing (Berninger, 2007) eta gaztelaniaz, Jiménezen (2018) Early Grade 
Writing assessment (EGWA), azken hau Kanariar Uharteetako laginekin, LH3. mailara arte. Jiménezek (2017) dionaren arabera, gaztelaniaz, falta dira garapeneko idazketaren eta bere zailtasunen ikerketa longitudinalak, zailtasunak dituztenen kopuruak eta zailtasunen araberako esku-hartzeak. Euskaraz, estandarizatutako probak argitaratu arte, LHko ikasleen idatzietan zailtasunak identifikatzen hasteko proposamen bat egiten dugu, egiaztapen-zerrenda bat hain zuzen ere, etorkizunean balioztatu beharrekoa. Eskuhartzeei dagokionez, marko teorikoan zehar azaltzen diren egileek eginikoa eta euskaraz dauden baliabideak kontutan hartzen dira, geroago azalduko den 'Esku-hartzeari Erantzuna' (Response to Intervention) ikuspuntuan, Tier1 mailan kokatzeko asmoz.

Artikulu honetan, 2. atalean, garapeneko idazketa eta bere zailtasunak ulertzeko hiru eredu teoriko azalduko dira; gero, neuropsikologikoak eta hizkuntzakoak diren zailtasunetan sakontzen da. 3. atalean, sortutako egiaztapen-zerrenda erakusten da, egon daitekeen zailtasun bakoitzerako azalpenak, adibideak eta esku-hartze estrategiak/baliabideak eskaintzen direlarik. Azkenik, 4. atalean, eztabaida eta ondorioak aipatzen dira.

\section{Garapeneko idazketaren zailtasun neuropsikologikoak eta hizkuntzakoak ikuspuntu kognitiboan}

Washingtoneko Unibertsitateko Berninger irakaslea eta lankideak 1991. urtean hasi ziren idazketaren ezgaitasunak ebaluatzeko edota esku hartzeko eredu teorikoa garatzen, ikuspegi kognitiboaren barnean. 'Idazketaren jabetzaren garapeneko zailtasunen eredu teorikoa' deitu zioten. Ondoren, osatzen joan izan dira eredua, eta artikulu honetan proposatzen den egiaztapen-zerrendarako egokiak direnak azalduko dira: Berningerren eta Swansonen (1994) 'Idazketaren garapeneko eredua' eta Berninger et al.en (2010) 'Hitzaren Forma Hirukoitzaren' teoria (Triple Word Form Theory). Hala ere, ezin ahaztu proposatu zuten 'Idazketaren ikuspegi sinplea' (Berninger eta Graham, 1998), 'Transkripzioaren eta funtzio exekutiboen eredua' (Berninger eta Amtmann, 2003), 'Idazketaren ikuspegi ez oso sinplea' (Berninger eta Winn, 2006) eta 'Idazketazailtasunak dituztenentzako idazketa-eredua' (Hayes eta Berninger, 2014). Jarraian, artikulu honetarako esanguratsuenak direnak azalduko dira.

'Idazketaren jabetzaren garapeneko zailtasunen eredu teorikoaren' arabera (Berninger et al, 1991), idazketa eragozten duten aldagaiak hiru motatakoak dira: zailtasun 
neuropsikologikoak, hizkuntzarekin loturiko zailtasunak eta zailtasun kognitiboak. Honela, zailtasun neuropsikologikoak dira: alfabetoko letrak segidan eta buruz ezin egitea, kodetze ortografikoari eta fonologikoan egon daitezkeen gabeziak, e.a. Bestalde, hizkuntzarekin loturiko zailtasunei dagokienez, marko teoriko honen arabera, zailtasun hauek hizkuntza prozesatu edo ekoizten den hiru mailatan eman daitezke: i) hitz-mailan, ii) esaldi-mailan eta iii) testu- edo paragrafo-mailan. Azkenik, kognizioarekin loturiko zailtasunak dira: plangintzarekin, translazioarekin (testu-sorkuntzarekin) eta errebisioarekin loturikoak, Hayesek eta Flowerrek (1980) proposaturikoak hain zuzen ere. Beraz, kognizioarekin loturiko zailtasunak dira, besteak beste, plangintzarik ez egitea eta errebisatzeko estrategia egokiak ez erabiltzea.

Berningerren eta Swansonen (1994) 'Idazketaren garapeneko ereduaren' arabera, hiru idazketa-garai nagusi daude: 9 urtera arteko garaia, 9-12 urteko garaia eta 12 urtetik aurrerakoa. Honela, 9 urtera arte, letrak egitea eta ortografia egokiarekin idaztea ez da prozesu mekanikoa. 9-12 urteko tartean, haur-idazle gehienek nahiko automatizatuta izaten dute letrak idaztea. Tarte honetan, testu-sorkuntza garatu egiten da hitz-, esaldi- eta paragrafo-mailan, eta idatzi ondorengo errepaso-gaitasuna ere garatu egiten da. Gainera, testua idatzi aurretiko plangintza ere garatuz joaten da. 12-15 urteko tartean, hobetzen joango da minutuko idazten den hitz eta esaldi kopurua eta baita idatzi ondorengo errepasoa ere.

Berninger et al.-en (2010) 'Hitzaren Forma Hirukoitzaren teoriaren' arabera, laneko oroimenean unitateak daude, fonologiarako, ortografiarako eta morfologiarako. Hau da, laneko oroimenean, ahoz esaten den hitza (fonologia), idatzizko hitza (ortografia) eta hitzaren estruktura (morfologia) biltzen, analizatzen eta prozesatzen da. Hitzaren hiru forma hauek (fonologiak, ortografiak eta morfologiak) idazketan eta irakurketan eragiten dute. Beraz, idaztearen eta irakurketaren prozesua hitzaren hiru forma hauetaz eta barruan dauden zatiez konturatzea eta koordinatzea da; eta, arazoak egon daitezke hitzaren forma bakoitzean edota hiruren koordinazioan. Hiru hitz forma hauen progresioa ez da lineala, nahastuta bezala baitaude garapenean. 


\subsection{Idazketa-zailtasunen identifikazioa eta esku-hartzea}

Estatu Batuetan ikasteko zailtasunak identifikatzeko 'Esku-hartzeari Erantzuna' deritzon ikuspuntua (Response to Intervention) proposatu zuen Hezkuntza sailak, zehazki Individuals with Disabilities Education Improvement Actek (IDEA). 3 maila zituen eredu honek: Tier1, Tier2 eta Tier3. Honela, Tier1 maila, screening unibertsala litzateke, ikasle guztiak urtean 3 aldiz irakurketan, idazketan eta matematiketan ebaluatzea. Ebaluazio hauetan emaitza pobreak dituztenak arrisku kategorian jartzen dira eta aurrerapenak monitorizatzen dira. Ikasle hauek ez badute Tierl mailako esku-hartzeetan erantzuten, Tier2 mailan kokatzen dira eta esku-hartzeak zehatzagoak dira. Maila honetan egonda, esku-hartzeei ez badiete erantzuten, Tier3 mailan kokatzen dira. Maila honetan ikasleagoaren \% 2tik \% 7ra egon ohi da eta hezkuntza bereziko zerbitzuetara bideratzen dira (Thoenes, 2016).

Oro har, irakurketaren identifikazioa eta esku-hartzea idazketa baino aurreratuago dago, 2004 geroztik proposaturiko Response to Intervention ikuspuntuan ere bai, batez ere Tier 1 mailari dagokionez (Philipakkos eta Fitzpatrick, 2018). EAEn 'Irakurketa Plana' dago martxan (Eusko Jaurlaritza, 2018) eta Espainia mailan Ministerio de Cultura y Deportek (2021) 'Plan de Lectura 2017-2010' dauka. Ez dago ordea, Idazketa-Planik. Hala ere, nazioartean garatzen joan dira probak eta saio bereziak Tier1, Tier2 eta Tier3 mailetarako. Proba eta saio horiek idazketako, irakurketako eta matematikako zailtasunetan esku hartzeko izan dira. Ikus gaztelaniaz, irakurketarako ECRA tresna (Jiménez, Gove, Crouch eta Rodríguez, 2014) eta matematikarako EGMA tresna (https://labur.eus/18iJb). Ingelesez, idazketarako, aipagarriak dira Berningerren $(2007,2015)$ eta Berningerren eta Wolfen (2016) lanak.

Idazketa ahalbidetzeko azpi-trebeziak askotarikoak dira eta azpi-trebezia hauekin loturiko zailtasunak muga izan daitezke idazterakoan. Jarraian, azpi-trebezia neuropsikologikoekin loturiko zailtasunak eta hizkuntzaren zailtasunak identifikatzeko eta esku hartzeko argibideak ematen dira, bereziki Berninger eta lankideek argitaratutakoa kontutan hartuta. Azpi-trebezia neuropsikologiko hauetako batzuk irakurketarekin lotuta daude. Euskaraz, irakurketan eta Haur Hezkuntzan funtsezkoak diren azpi-trebeziak deskribatu izan dira, esku hartzeko ariketak ere proposatu direlarik (Romero-Andonegi, Tejadak eta Garayk, 2017). 


\subsubsection{Azpi-trebezia neuropsikologikoak eta bere zailtasunak}

a) Alfabetoko letrak buruz segidan idaztea (integrazio ortografiko-motorea)

Alfabetoko letrak buruz segidan eta akatsik gabe ezin badira idatzi, haurrak zailtasunak izango ditu testua eta bertako edukia idazteko (Berninger et al., 1991). Zailtasun mota hori dagoen aztertzeko "Alfabetoaren proba" erabili izan da: test forman erabiltzen den bertsioan (Berninger, 2007): 15 segundotan alfabetoa letra xehez, ulergarri eta ordenean idaztea eskatzen da. Alfabetoaren proba horrek integrazio ortografiko-motorea deritzona neurtzen du (Berninger et al., 2001). Gurean, Ibarrak (2016) euskarara egokitu zuen proba hau 552 ikaslerekin eta taldean pasatzeko minutu batean egiteko eskatzen zuen. Horrela, alfabetoko letrak (xehez eta larriz) azkar egitea eskatzen da. Ondoren, letrek berrukitua badute, letrak jan badira, ordena aldatu bada edo denbora luzez egon bada, esku hartu egin beharko litzateke.

Esku-hartzea akats-moten araberakoa da; adibidez, letrek berrukitua badute, letraformakuntza landu behar da, eta letrak jan badira, alfabetoaren sekuentzia erakutsi behar da (Ibarra, 2019).

\section{b) Integrazio biso-motorra}

Ikusmenezko pertzepzioaren eta atzamarren mugimenduen arteko koordinazio bezala definitu zuen Beeryk (2004). Koordinazio hori ondo integratuta ez egotea ere oztopo bat da idazterakoan (Berninger et al., 1991). Klasikoak izan dira integrazio biso-motorra ebaluatzeko 'Beeryren testa' (Beery, 1982) eta 'Bender testa' (1946). Test hauek zenbait formen kopian oinarritzen dira. Integrazio biso-motorraren zailtasunek idazketarekin harreman estua dute (bereziki letren irakurgarritasunarekin) eta idazketaren zenbait ezaugarritan antzeman daitezke, hala nola, letren guneetan proportzio ezak daudenean, hitzen artean tarte irregularrak daudenean, letren arteko loturak ulergarriak ez direnean, etab.

Esku-hartzea egiteko, 'Beeryren testa'ren argibideak jarraitu daitezke, edo afektatuta dagoen ezaugarri horretan esku hartu daiteke zuzenean (adibidez, hitzen tarte erregularrak egiten). 


\section{d) Kodetze fonologikoa-ortografikoa}

Hitzak idaztea kode fonologikoak eta kode ortografikoak zehatz 'orkestatzean' datza (Berninger et al., 1991). Kodetze fonologikoa ahoz esaten diren hitzen adierazpena eta analisia laneko oroimenean gordetzea da (Berninger et al., 2001). Kodetze ortografikoa, laneko oroimenean hitz idatzia gorde eta, ondoren, hitza, letra bat edo letra-multzoa gogoratu edo adieraztea da (Berninger et al., 1992). Arazoak kodetze fonologikoan edo kodetze ortografikoan edo bi kodeen arteko konexioan egon daitezke (Berninger et al., 1991). Honela, arazo hauek zehatz identifikatzeko, hitzak, letrak, letra-multzoak, kode fonetikoak, kode fonemikoak eta silabak/errimak erabiltzen dira (Berninger et al., 2001).

Esku-hartzea kontzientzia fonologikoa eta kontzientzia ortografikoa sustatzean datza. Kontzientzia fonologikoari dagokionez, printzipio alfabetikoa lantzea garrantzitsua da. Printzipio alfabetikoa letrak bere soinuarekin elkartzean datza. Adibidez, $m$ letra idatziz ikusi eta $/ \mathrm{mmm} /$ soinua duela dakien haurrak badaki printzipio alfabetikoa (National Center on Improving Literacy, 2020). Printzipio alfabetikoak bi jakintza biltzen ditu eta berauek garatzea komeni da: i) letrak erabiliz hitzak osatzen direla jakitea eta ii) hitzaren soinuak ordezka daitezkeela jakitea, letra batzuekin edo besteekin. Euskaraz (eta gaztelaniaz), fonema-grafema loturak, hau da, entzuten ditugun soinuen eta idazten ditugun letren arteko loturak, nahiko zuzenak dira (testuinguru ezberdinetan fonema bat = letra bat), ingelesarekin edo frantsesarekin alderatuz (Antzaka et al., 2018). Euskaraz, adibidez, 'a' bokalaren soinua /a/ eta grafema 'a' beti berdina da, ez adibidez ingelesez: soinu desberdina baita mat /mæt/ eta mate/mert/ hitzetan. Entzuten den fonema bakoitza grafema batekin idazteari ortografia naturala deritzo eta hizkuntza batzuetan beste batzuetan baino aldaera handiagoa dago fonemen eta grafemen arteko lotura horretan. Bestalde, fonema-grafema artean irregulartasunak daude hitz batzuetan, adibidez, zenbait soinuk bi grafema dituzte. Irregulartasun horiek ortografia arbitrarioaren barnean sartzen dira.

Kontzientzia ortografikoari dagokionez, bere sustapenerako ondo funtzionatzen dute 'begiratu eta esan' jolasek, looking games deiturikoak (Berninger, 2015). Jolas horietan, hitz bat erakusten da eta haurrari begiak ixtea eskatzen zaio. Ondoren, haurrak bere buruaren barruan ikusten du hitza, eta galderak egiten zaizkio begiak ireki gabe hitzaren letra guztiei buruz, letra bati buruz edo posizio desberdinetan dauden letra-multzoei buruz. 


\section{d) Kodetze morfologikoa}

Esanahia duten ahozko hitz zatiak (lexemak edo morfemak) laneko oroimenean izan eta idatzira ahalegin handirik gabe pasatzeko gaitasuna da (Berninger eta Swanson, 2013). Kodetze morfologikoa aztertzen du ingelesez Pal-II Reading and Writing testak (Berninger, 2007).

Kodetze morfologikoa sustatzeko, kontzientzia morfologikoa lantzea komeni da eta Dyslexia Help (2020) webgunean aurkitu ditzakegu zenbait estrategia, hala nola, hitzen erroak aurkitzea, aurrizkiak eta atzizkiak emanda hitzak sortzea, atzizkien eta aurrizkien arabera hitzak multzokatzea, morfema zehatz batekin hasten diren ahalik eta hitz gehien gogoratzea, e.a.

\subsubsection{Hizkuntzaren mailak eta bere zailtasunak}

Berninger et al.en (1991) arabera, hizkuntzaren zailtasunak hizkuntza prozesatu edo ekoizten den hiru mailatan eman daitezke: i) hitz-mailan, ii) esaldi-mailan eta iii) testu edo paragrafo-mailan. Labur esanda, prozesatzea irakurtzea litzateke eta ekoizpena idazketa. Horrela, hizkuntzaren prozesatzearekin dauden zailtasunak antzeman daitezke: 'miaha' aurkeztuz gero 'mahaia' ezin denean irakurri, esaldi bateko elementuak nahastuta jarri eta esaldia zein den ezin denean asmatu, edo paragrafo bat nahastuta emanda, paragrafoa ezin denean ondo antolatu. Bestalde, hizkuntzaren ekoizpenaren zailtasunak ondoko egoeretan antzeman daitezke: irakasleak ahoskatu duen hitza ezin denean idatzi; hitz batzuk eman eta hitz horiekin esaldi bat asmatzeko esandakoan, esaldia idatzi ezin denean; edota esaldi bat eman eta paragrafo bat idazteko esandakoan, paragrafoa idatzi ezin denean.

Aipaturiko egileen arabera, hizkuntzaren prozesatzearekin eta ekoizpenarekin loturiko zailtasun horiek bata bestearengandik desberdinak dira eta tratamendu desberdindua behar dute. Bestalde, Berningerren eta Swansonen (1994) ereduaren arabera, hitz, esaldi eta paragrafo mailaren garapena desberdina da pertsonatik pertsonara, eta maila bakoitza beste mailetatik nahiko independentea da; hau da, hitz mailako trebeziak ez du aurresaten esaldi mailako trebezia, eta esaldi mailako trebeziak ez du aurresaten paragrafo mailako trebezia. 


\section{Idazketa zailtasunetarako egiaztapen-zerrenda}

Aipaturiko zailtasun neuropsikologikoak eta hizkuntzakoak haur guztien idatzietan aztertzea eta horiek goiz identifikatzea oso garrantzitsua da. Izan ere, zailtasun horiek badaude, haurrek kostata idatziko dute (Apel eta Werfel, 2014). Gainera, zailtasuna arlo batean edo bestean egon, esku-hartze bat edo beste proposatu beharko da. Bestalde, azpitrebezien eta hizkuntza mailen artean harremanak daude eta koordinatuz doaz (Berninger et al., 2008), nahiz eta oraindik orain ez den argi erakutsi trebezia eta zailtasunen arteko lotura horiek non hasten eta bukatzen diren.

Horrez gain, kontutan izan behar da laneko oroimenari egiten zaion eskaera kognitiboa desberdina dela eskatzen den idazteko zeregina bat ala beste izan. Honela, Australian Staatsek, Oakleyk eta Maraisek (2019) erakutsi dutenez, diktaketa zailagoa da kopiatzea baino eta testua konposatzea zailagoa da diktaketa baino.

Oro har, LHko 1. mailako haurrek (6 eta 7 urte bitarteko haurrek), letra-soinuaren aurkikuntza egina dute; hau da, printzipio alfabetikoa lortuta dute, curriculumaren arabera, Haur Hezkuntzan landu dutelako. Ordutik aurrera komeniko litzateke idazteko eta irakurtzeko zailtasunak dauden aztertzea eta horien zergatia zein den begiratzea.

Jarraian, idazketa-zailtasunak identifikatzeko egiaztapen-zerrenda bat proposatzen dugu (1. taula).

Taula horretan egiaztapen-zerrendan agertzen diren itemak azalduko ditugu. Egiaztapenzerrenda hau koloreetan antolatuta dago, azpi-trebezia bakoitzak kolore bat du: i) kodetze fonologikoa berdez dago, ii) kodetze ortografikoa lila kolorez, iii) kodetze morfologikoa urdinez, iv) integrazio ortografiko-motorea grisez eta v) integrazio biso-motorra horiz. Ondoren, itemak sailkatu dira, azpi-trebezien arabera eta itemen operatibizazioa ematen da (ikus 2. taula). 
1. taula. Idazketa-zailtasunen egiaztapen-zerrenda.

\begin{tabular}{|c|c|c|}
\hline \multicolumn{3}{|c|}{ IDAZKERA-ZAILTASUNEN EGIAZTAPEN-ZERRENDA } \\
\hline \multicolumn{3}{|c|}{$\begin{array}{l}\text { (x jarri BAI bada erantzuna). Kolorea duten atalak hutsik gelditzen badira, seinale ona da. Aldiz, } \\
\text { kolorea dutenak x-arekin gelditzen badira, barruan dauden azpiatalak begiratu behar dira. }\end{array}$} \\
\hline $\begin{array}{l}\text { 1. Entzuten den moduan idazteko } \\
\text { zailtasunak. Printzipio alfabetikoa } \\
\text { jarraitzeko zailtasunak }\end{array}$ & $\begin{array}{l}\text { 4. Alfabetoaren proban letrak } \\
\text { ordenean idazteko zailtasunak }\end{array}$ & $\begin{array}{l}\text { 7. Hitzen arteko tarteetan } \\
\text { zailtasunak (idazlearen } m \\
\text { letraren zabalera) }\end{array}$ \\
\hline Omisioak & Letrak jan ditu & $\begin{array}{l}\text { Tarte estuegiak ( } m \text { letra } \\
\text { baino estuagoak) }\end{array}$ \\
\hline Ordezkapenak & Letrak posizioz aldatu ditu & $\begin{array}{l}\text { Tarteak zabalegiak }(m \\
\text { letraren zabalagoak })\end{array}$ \\
\hline \multicolumn{3}{|l|}{ Inbertsioak } \\
\hline $\begin{array}{l}\text { 2. Hitzak modu konbentzionalean } \\
\text { banatzeko zailtasunak }\end{array}$ & $\begin{array}{l}\text { 5. Hizkuntza arau ortografikoak } \\
\text { jarraitzeko zailtasunak }\end{array}$ & $\begin{array}{l}\text { 8. Letren arteko loturetan } \\
\text { zailtasunak }\end{array}$ \\
\hline $\begin{array}{l}\text { Hitz-barruak modu desegokian } \\
\text { banatuta }\end{array}$ & $z$ erabiltzen du $t z$ erabili ordez & $\begin{array}{l}\text { Lotura diagonalak ez dira } \\
\text { ulergarriak }(e l, f e, e g \ldots)\end{array}$ \\
\hline \multirow[t]{2}{*}{ Bi hitz modu desegokian elkartuta } & $r$ bakarra erabiltzen du $r r$ erabili ordez & $\begin{array}{l}\text { Lotura horizontalak ez dira } \\
\text { ulergarriak }(b i, v i, o i, b r, b e)\end{array}$ \\
\hline & $h$ letraren erabilpen okerra & $\begin{array}{l}\text { Digrafoak dituzten loturak } \\
(t x, \quad t s, \quad t z, \quad t t) \text { ez dira } \\
\text { ulergarriak }\end{array}$ \\
\hline $\begin{array}{l}\text { 3. Letra bakoitza ulergarri uzteko } \\
\text { zailtasunak. }\end{array}$ & $\begin{array}{l}\text { 6. Letrak erregularrak izateko } \\
\text { zailtasunak }\end{array}$ & $\begin{array}{l}\text { 9. Erritmoan zailtasunak } \\
\text { daude. }\end{array}$ \\
\hline $\begin{array}{l}o, a, d, g, c, q \text { (1. familiako letraren } \\
\text { bat ez da ulergarria) }\end{array}$ & Letren erdi-gunea irregularra & \begin{tabular}{|ll}
$\begin{array}{l}\text { Geldiro idazten } \\
\text { ikasmailarako } \\
\text { oharra azpian) }\end{array}$ & $\begin{array}{l}\text { (begiratu } \\
\text { (bere }\end{array}$ \\
\end{tabular} \\
\hline $\begin{array}{l}e, l, b, f, h \text { (2. familiako letraren bat } \\
\text { ez da ulergarria) }\end{array}$ & Letren goiko aldea txikiegia/handiegia & $\begin{array}{l}\text { Azkarregi idazten du eta } \\
\text { kostata ulertzen da idazten } \\
\text { duena }\end{array}$ \\
\hline $\begin{array}{l}n, \tilde{n}, m, p \text { (3. familiako letraren bat } \\
\text { ez da ulergarria) }\end{array}$ & \begin{tabular}{|l|}
$\begin{array}{l}\text { Letren beheko } \\
\text { txikiegia/handiegia }\end{array}$ \\
\end{tabular} & \\
\hline $\begin{array}{l}r, s, x, z \text { (4. familiako letraren bat ez } \\
\text { da ulergarria) }\end{array}$ & & 10. Eroso idazten du \\
\hline $\begin{array}{l}u, y, v, w \text { (5. familiako letraren bat } \\
\text { ez da ulergarria) }\end{array}$ & & $\begin{array}{l}\text { Orria ez du behar bezala } \\
\text { jartzen }\end{array}$ \\
\hline $\begin{array}{l}i, j, k, t \text { (6. familiako letraren bat ez } \\
\text { da ulergarria) }\end{array}$ & & $\begin{array}{l}\text { Idaztresnari ezeroso heltzen } \\
\text { dio }\end{array}$ \\
\hline
\end{tabular}

Proposatzen den egiaztapen-zerrenda Tierl mailarako litzateke, hots, ikaslego guztiari pasatzeko, urtean hiru aldiz, momentuz fidagarritasunik eta balioztapenik ez badu ere. Bertan, LH1etik LH6rako ikasmailetan idaztean, gure ustez, gainbegiratu beharko liratekeen zailtasunak agertzen dira. Idazkera argiago edota azkarrago bat izateko, egiaztapen-zerrendan agertzen den ordena horretan esku-hartzea proposatzen da. Hau da, 
lehenengo 1. itema begiratu eta zailtasunak egonez gero, esku hartu. Ondoren, 2. itema begiratu eta zailtasuna egonez gero, esku hartu, eta horrela beste item guztiekin. Izan ere, haurren garapenean, lehenik, entzuten dutena fideltasunez idazten saiatzen dira, hots, ortografia naturalari jarraituz; ondoren, hitzak modu konbentzionalean zatitzen joaten dira eta pixkanaka ortografia arauak (arbitrarioa) aplikatzen saiatzen dira. Progresioa ezartzeko, kontuan hartu da Berningerren eta Swansonen (1994) “Idazketaren garapeneko eredua". Hala ere, egiaztapen-zerrendako ordena etengabe egokitu beharko da ikasle bakoitzaren idazkeraren ezaugarrietara.

2. taula. Egiaztapen-zerrendako itemak sailkatuta azpi-trebezien arabera eta itemen operatibizazioa.

\begin{tabular}{|c|c|c|}
\hline AZPI-TREBEZIAK & ITEMAK & ITEMEN OPERATIBIZAZIOA \\
\hline Kodetze fonologikoa & 1 & Fonema-grafema akatsak \\
\hline Kodetze ortografikoa & 5 & $\begin{array}{l}\text { Ortografia arauetan akatsak, digrafoak ez erabiltzea edota erabat } \\
\text { arbitrarioak diren hitzetan akatsak }\end{array}$ \\
\hline Kodetze morfologikoa & 2 & Hitzak banatzeko orduan akatsak \\
\hline $\begin{array}{l}\text { Integrazio ortografiko- } \\
\text { motorea }\end{array}$ & 4 & Alfabetoaren probaren akatsak \\
\hline \multirow{6}{*}{$\begin{array}{l}\text { Integrazio biso- } \\
\text { motorra }\end{array}$} & 3 & $\begin{array}{l}\text { Marra guztiak dituzten letrak, berrukiturik gabekoak eta hitza } \\
\text { soilik irakurrita bere horretan ulertzen dena }\end{array}$ \\
\hline & 6 & $\begin{array}{l}\text { Letren erdialdea, goiko aldea edota beheko aldeak oso txikiak } \\
\text { edo oso handiak egitea }\end{array}$ \\
\hline & 7 & Hitzen arteko tarteak estuegiak edo zabalegiak \\
\hline & 8 & $\begin{array}{l}\text { Lotura diagonaletan, lotura horizontaletan edo digrafoen } \\
\text { loturetan akatsak }\end{array}$ \\
\hline & 9 & ‘Kopia azkarraren proban’ bataz bestekotik behera egotea \\
\hline & 10 & Eskua-orria eroso ez egotea \\
\hline
\end{tabular}

Egiaztapen-zerrendan, kodetze fonologikoaren, kodetze ortografikoaren, kodetze morfologikoaren, integrazio ortografiko-motorearen eta integrazio biso-motorearen zailtasunak agertzen dira. Dena ulerterrazago egiteko, honela jokatuko dugu: hasiera batean i) zailtasunaren azalpena emango da eta aipaturiko eredu teorikoez gain, beste egile batzuen ekarpenak emango dira; ahal denean, euskarara egokituko da azalpena; gero, ii) adibideak erakutsiko dira eta iii) azkenik, item bakoitzean esku-hartzeko baliabideak proposatuko dira. Adibidez, hitzak ondo ez banatzeak kodetze morfologikoarekin du zerikusia eta interesgarria izan daiteke, adibidez, hizki-sopak proposatzea. Garrantzitsua da esatea, esku-hartzea eginez gero, hobekuntza bakarraren 
bila joan behar dela. Esaterako, hitzen banaketa lantzen ibiliz gero, ez eskatu haurrari 'arrtoa' 'r' bakarrarekin idaztea ere. Hala ere, egia da zenbait itemek elkarren arteko lotura dutela; adibidez, 1, 2 eta 5 itemek (ikus aurrerago).

\subsection{Entzuten den moduan idazten du? Printzipio Alfabetikoa jarraitzen du?}

Fonemak grafemekin idazterakoan akatsak egin daitezke, hala nola omisioak, ordezkapenak edota inbertsioak: i) omisioak gertatzen dira idazleak ez duenean fonema bati dagokion grafema jartzen ii) ordezkapenak egiten dira fonema bati dagokion grafema beste grafema baten bidez jartzen denean eta iii) inbertsioak egiten dira sekuentzia fonetikoek ez dutenean sekuentzia grafemikoarekin bat egiten (Granados eta Torres, 2016). Akats horiek ohikoak izaten dira idazten ikastean (ikus adibideak 3. taulan), baina komeni da jarraipen estua egitea, bestelako akatsik dagoen ikusteko eta ahalik eta arinen esku hartzeko.

Ondoren, 3. taula azalduko dugu. Lehenik, item bakoitzaren azalpena emango da, gero, adibideak erakutsiko dira eta, azkenik, item bakoitzean esku hartzeko estrategiak proposatuko dira. Adibideak, eskola bateko irakasleekin eginiko formakuntzatik ateratakoak dira.

Esku-hartze proposamenari dagokionez, mota horretako akatsak agertzen direnean kontzientzia fonologikoa sustatu behar da. Eta horretarako oso ondo zehaztu behar da haurrak zein ariketa behar duen. Euskaraz, 'Irakurgunea' webgunean (Eusko Jaurlaritza, 2020) azaltzen diren baliabideak erabili daitezke, esaterako. 
3. taula. Letrak idaztean akatsak.

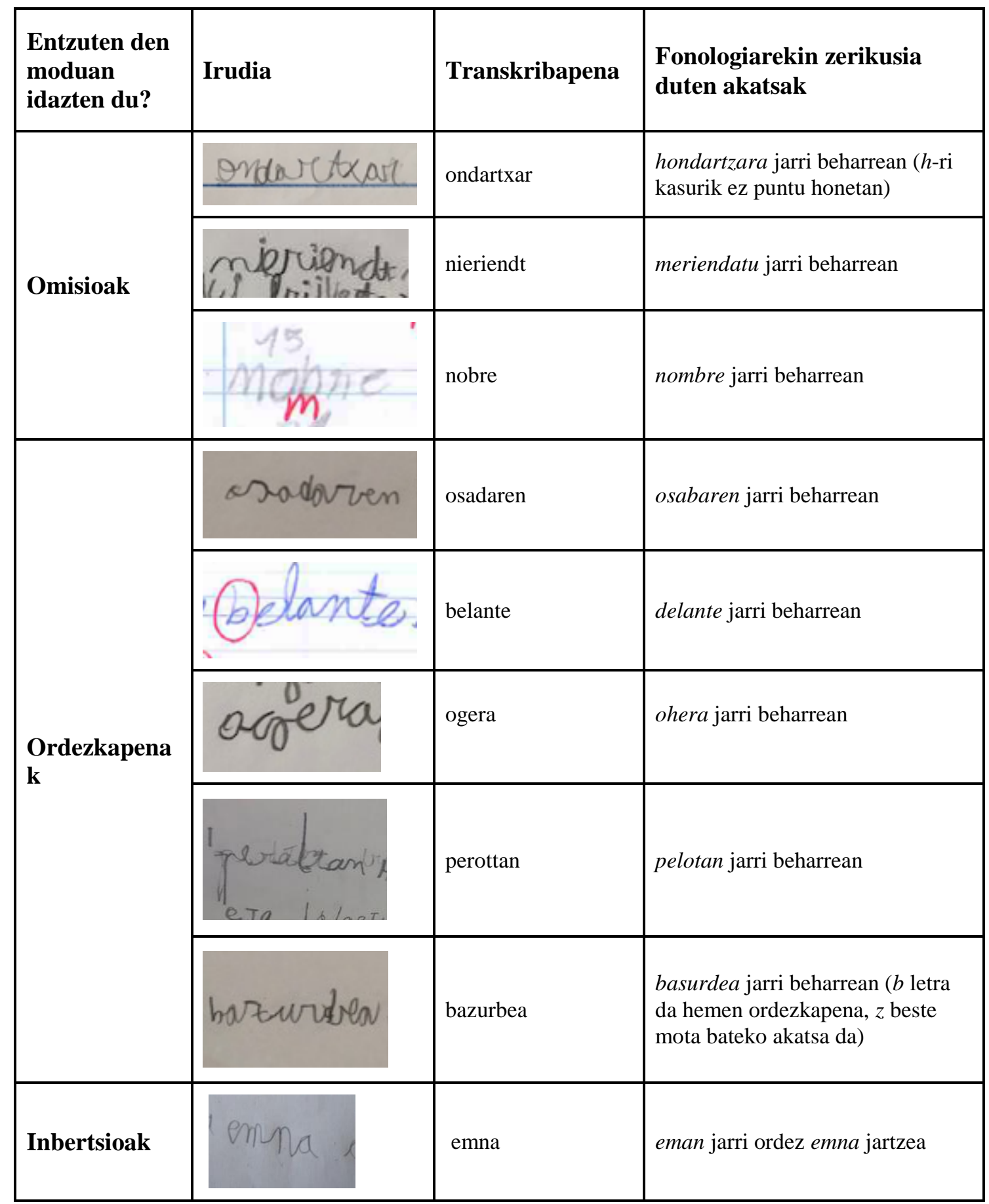

Haurrek ohikoenak dituzten hitzak erabiltzeak asko laguntzen du (esaten dituztenak eta idatziz ikusten dituztenak) ariketak proposatzean (Berninger, 2015). Sarasolak (2015) adibidez, helduengan ohikoenak diren euskarazko hitzak bildu ditu, helduen hitzen corpusak erabiliz. Entzuten dena ondo idazteko, hitz horietatik Haur Hezkuntzan eta LHn 
zehar ohikoenak diren hitzak erabiltzea gomendatzen dugu. Hasiera batean, printzipio alfabetikoa sustatzeko, entzuten diren bezala idazten diren hitzak aukeratzea komeni da. Printzipio alfabetikoa jarraitzen duten hitzak dira adibidez, beti, gero, ari, egin, bera, nola, alde, lan, gu, ni, etab. Adibidez, ez da komeni hitz-mota hauek lantzea lehen fasean:

- Digrafoak dituzten hitzak (soinu afrikatuak): $t x, t s, t z$ eta $t t$ duten hitzak.

- Hegoaldean $h$ letra duten hitzak ('ahate' hitza nahasgarria gertatu daiteke).

- Ahoskatzerakoan $z$ eta $s$ desberdintzen ez den tokietan, ez erabili $z$ eta $s$ duten hitzak.

- $r$ dardakari gogorra ahoskatu eta $r$ bakarrarekin idazten diren hitzak ez erabili ('artoa' bezalako hitzak ez erabili).

Ortografia naturalari dagokionez, haurrek akatsak egiten badituzte grafema-soinuen korrespondentzia honetan, komeni da aztertzea, akats hori, omisioa, ordezkapena ala inbertsioa den. Letren omisio-akatsak badaude, interesgarria izan daiteke 'oroimenariketak' egitea (begiratu egiaztapen-zerrendako 4. puntua). Ordezkapenak badaude, komeni da konprobatzea haurrak ondo ahoskatzen duen edota ondo entzuten duen. Izan ere, haurrak ahoskatzen duen moduan idatziko du. Adibidez haurrak 'ogera' esaten badu 'ohera' esan beharrean, 'ogera' idatziko du ziurrenik. Kontuan izan baita, euskalkian idatziko dela askotan ('joan’ jarri beharrean ‘jun’ idatziko dela).

\subsection{Hitzak modu konbentzionalean banatzen ditu?}

Hitzak modu konbentzionalean banatzeak morfologiarekin eta esaldiekin du zerikusia, arau morfo-sintaktikoekin, hain zuzen ere. Haurrak hitzak hipersegmentatu egin ditzake, hau da, erdibitu edo hiposegmentatu egin ditzake, horretarako bi hitz (edo bi hitzen zatiak) bilduz (Ibarra, 2009a), 4. taulan erakusten dugun moduan. 
4. taula. Hitzen banaketa.

\begin{tabular}{|l|l|l|l|}
\hline Hitzen banaketa & Irudia & Transkribapena & $\begin{array}{l}\text { Morfologiarekin zerikusia } \\
\text { duten akatsak }\end{array}$ \\
\hline Hipersegmentazioa & imgr ren & i nge ren & $\begin{array}{l}\text { Hitza banatuta dago modu } \\
\text { desegokian }\end{array}$ \\
\hline Hiposegmentazioa & gloringenuen & egingenuen & $\begin{array}{l}\text { Bi hitz elkartu ditu modu } \\
\text { desegokian } \\
\text { Bi hitz elkartu ditu modu } \\
\text { desegokian (herrian esaten den } \\
\text { moduan ere idatzi du) }\end{array}$ \\
\hline
\end{tabular}

Esku-hartze proposamenari dagokionez, hitzen banaketa hobetzeko, kontzientzia morfologikoa sustatzea komeni da. Zerrenda batean jarri beharko lirateke haurrak modu desegokian edo ez konbentzionalean banatzen edo elkartzen dituen hitzak. Zenbait hitz erdibitu gabe idazten direla konturatzeko, komenigarria da hitzak nolakoak diren erakustea. Horretarako, morfema bera erabiltzen duten hitzen familiak erabiltzea komeni da, hau da, morfema berdinarekin sorturiko hitzak. Adibidez, aba morfemarekin osaturiko hitzen familia da, asaba, osaba, izeba, iloba, alaba, arreba, neba eta ugazaba. Horrez gain, lagungarria izan daiteke ‘Atzekoz aurrera' hiztegia erabiltzea (UZEI, 1994). Zeregin horretan, hau da, zenbait hitz erdibitu gabe idazteko orduan, ez du laguntzen semantikoki harremanduta dauden hitzen familiak erakusteak (azken hauek esanahia partekatzen dute). Adibidez, goiko adibidean 'inge ren' erdibituta idatzi duen haurrari 'ren' morfemarekin dauden hitzak erakutsi behar zaizkio. Honela, 'amonaren', 'osabaren', 'zuhaitzaren' hitzak jarriko dira haurraren begibistan. Kasu horretan, hizkisopak, gurutzegramak eta anagramak sortu daitezke 'ren' morfemarekin (ikus 5. taula).

5. taula. Aurkitu 'amonaren' eta ‘etxearen' hitzak.

\begin{tabular}{|l|l|l|l|l|l|l|l|}
\hline N & E & X & U & G & N & E & R \\
\hline A & M & O & N & A & R & E & N \\
\hline N & E & R & A & E & X & T & E \\
\hline
\end{tabular}

Bestetik, haurrak bi hitz bildu baditu eta banatuta idazten direla konturatzea nahi badugu, komenigarria da mota honetako hitzak esaldietan banatuta idazten direla erakustea. Adibidez, ‘joanziren’ idatzi duen haurrari, begibistan jarriko genizkioke 'joan ziren' motako esaldiak. Ikus Txikipediatik erauzitako corpusean (“joan” lehenengo hitzaren 
forma eta "ziren" bigarren hitzaren forma jarrita) izandako bilaketako bi adibide (https://labur.eus/8oZln):

(1) 'Geroago, zati horiek pixkanaka-pixkanaka multzotan bilduz joan ziren; horietatik sortu ziren galaxiak, izarrak eta planeta-sistemak'.

(2) 'Eta, gainera, bizimodu nomada utzi eta sedentario bihurtuz joan ziren'

\subsection{Letra bakoitza ulergarri dago?}

Egiaztapen-zerrendan irakurgarritzat hartuko dira marra guztiak dituzten letrak, berrukiturik gabekoak eta hitza soilik irakurrita bere horretan ulertzen direnak (6. taula). Letren konplexutasun grafikoaren arabera, letrak familietan multzokatu daitezke. Hau da, letren ezaugarrien arabera, antzeko mugimenduak egiten dira eta mugimendu horien arabera letrak familietan antolatu ahal dira. Horixe egin zen 'Letra xeheak bai!' argitalpenean (Ibarra, Ortube eta Muxika 2020). Argitalpen horren arabera, letrak 6 familiatan bereiztu dira eta familiak hauexek dira. Lehen familia, $a, o, c, d$, $g$ eta $q$ letrak; bigarren familia, $e, l, b, f, h$ letrak; hirugarren familia $n, \tilde{n}, m, p$ letrak; laugarren familia, $r, s, x, z$ letrak; bosgarren familia, $u, y, v, w$ letrak eta seigarren familia, $i, j, k, t$ letrak. Adibidez, 1. familian, $a, o, c, d$, $g$ eta $q$ letrak daude, horiek denak eskuineko aldetik egiten hasten dira eta forma borobildua dute.

6. taula. Letren ulergarritasuna aztertzen.

\begin{tabular}{|c|c|c|c|}
\hline Letren ulergarritasuna & Irudia & Transkribapena & Azalpena \\
\hline $\begin{array}{l}1 \text { familiako letraren bat ez dago } \\
\text { ulergarri }(o, a, d, g, c, q)\end{array}$ & & qeue & $\begin{array}{l}q \text { letra ulergarri } \\
\text { ez }\end{array}$ \\
\hline \multirow{2}{*}{$\begin{array}{l}\text { 3. familiako letraren bat ez dago } \\
\text { ulergarri }(n, \tilde{n}, m, p)\end{array}$} & & donnekan & $\begin{array}{l}m \text { letra ulergarri } \\
\text { ez }\end{array}$ \\
\hline & & $\tilde{\mathrm{n}}$ & $\begin{array}{l}\tilde{n} \text { letra ulergarri } \\
\text { ez }\end{array}$ \\
\hline $\begin{array}{l}\text { 4. familiako letraren bat ez dago } \\
\text { ulergarri }(r, s, x, z)\end{array}$ & Lonpikanapem & lunnikanapen & $\begin{array}{l}r \text { letra ulergarri } \\
\text { ez }\end{array}$ \\
\hline
\end{tabular}

Esku-hartze proposamenari dagokionez, letra ez ulergarriak zein letra-familiatakoak diren aztertu behar da. Ondoren, Ibarra et al.en (2020) aipatzen den prozeduraren bitartez 
lantzea proposatzen dugu, lau pausotan. Honela: 1) irakasleak letraren forma ahots altuan esan dezala, 2) haurrak ere esan dezala ondoren, 3) letren gainean marraztutako geziak jarraituz haurrak mugimenduak berregin ditzala (ezer esan gabe, hitz egin gabe) eta 4) azkenik, eredurik gabe letraren mugimendua egin dezala.

\subsection{Alfabetoaren proban letrak ordenean daude? Letrak modu automatikoan eginda daude?}

Alfabetoaren proba eman (Ibarra, 2019). Egiten diren akatsek izaera eta esku-hartze desberdina dute.

Esku-hartze proposamenari dagokionez, haurrak letrak jaten baditu edota ordena aldatzen badu, komeni da alfabetoaren abestia kantatzea eta 'oroimen-ariketak' egitea. Galdetu egiozue haurrari: "Zein letra dago $c$ letraren aurrean? Eta zein atzean edo ondoren?". Komenigarria izan daiteke apurka-apurka trebatzea, alfabetoa hiru zatitan banatuz, alfabetoa aurrean dagoela, eta ondoren, letra bat aurretik eta ondorengo letra atzetik galdetuz (ez bi aurretik eta bi atzetik) (7. taula). 'Letrekin ekin' blogean (https://letrekinekin.blogspot.com/2019/11/4-saioa-alfabetoaren-proban-ez-daki.html) agertzen da hori egiteko azalpena eta alfabetoaren kanta ere bertan dago.

Kontuan izan behar dugu letretan berrukituak badaude edota letrak ez badira ulertzen, honakoa egitea proposatu behar zaiola: letra-formakuntza landu familiaka, 3. puntuan azaldu den bezala. Letra gutxi egin baditu, aztertu beharko da zergatia: letra guztiak ez jakitea izan daiteke arrazoi bat, eta orduan letra-formakuntza landu behar da. Letren ordena ez jakitea izan daiteke beste bat, eta orduan alfabetoaren segida hiru zatitan banatu eta segidak praktikatzen joan behar da. Beste batzuetan, motel idazten da, eta orduan azkarrago idazteko ariketak egitea komeni da (egiaztapen-zerrendako 9. puntua).

7. taula. Letren ordenan arazoak.

\begin{tabular}{|c|c|c|c|}
\hline Ordena & Irudia & Transkribapena & $\begin{array}{l}\text { Integrazio ortografiko- } \\
\text { motorean akatsak }\end{array}$ \\
\hline Letrak jan & $a$ l c c e \& m & $a b c d e f m$ & $g, h, I, j, k, l$ letrak jan ditu \\
\hline Letrak posizioz aldatu & & $\mathrm{fj} \mathrm{H}$ & $\begin{array}{l}j \text { letra posizioz aldatu du, } h \\
\text { letra zen }\end{array}$ \\
\hline
\end{tabular}




\subsection{Euskaltzaindiako arauak jarraitzen ditu (ortografia arbitrarioa)}

Ortografia arautua oinarri ortografikoan eta lexikoan oinarritzen da, hau da, ez da oinarritzen entzuten den horretan. Era berean, ortografia arbitrarioa arautua edo ez arautua izan daiteke (Jiménez et al., 2008). Ortografia arbitrario arautua arauak dira. Adibidez, $l$, $n$ edo $s$-ren ondoren $r$ bakarra idazten dela eta ez $r r$ bikoitza eta soinu batzuek korrespondentzia grafemiko bat baino gehiago izan ditzaketela (adibidez gaztelaniaz, que hitza). Ortografia arbitrario ez arautua kontu etimologikoa da, hau da, hizkuntza zehatz batetik datorren hitza hizkuntza horretan idazten den modua kontutan hartzen da. Adibidez, gaztelaniaz hiper $h$-rekin idazten da grekeratik datorren hitza delako, almohada hitza $h$-rekin idazten da arabieratik datorrelako eta curriculum hitza $c$-rekin latinezko hitza delako. Beraz, haurrak jakin behar du zenbait arau daudela, afrikatuen soinuak digrafoekin idazten direla (txakurra, otsoa, putzua) eta hitz batzuk agian arau jakin bat gabe idazten direla eta buruz jakin behar dituela. Hortaz, haurrak egiten dituen akatsak izan daitezke: arauak ez aplikatzea, digrafoak ez jartzea edota erabat arbitrarioak diren hitzak barneratuta ez izatea (ikus 8. taulako adibideak).

8. taula. Ortografia arbitrarioa.

\begin{tabular}{|c|c|c|c|}
\hline $\begin{array}{l}\text { Ortografia } \\
\text { arbitrarioa }\end{array}$ & Irudia & Transkribapena & Ortografian akatsak \\
\hline $\begin{array}{l}z \quad \text { erabiltzen du } t z \\
\text { erabili ordez }\end{array}$ & & ninzen & ez du erabili $t z$ digrafoa \\
\hline $\begin{array}{l}x \text { jartzen du } t x \text { erabili } \\
\text { ordez? }\end{array}$ & & exera & ez du erabili $t x$ digrafoa \\
\hline $\begin{array}{l}r \text { bakarra erabiltzen } \\
\text { du } r r \text { erabili ordez }\end{array}$ & & belara & $r r$-rekin idazten da \\
\hline $\begin{array}{l}\mathrm{z} \text { jartzen du s letraren } \\
\text { ordez? }\end{array}$ & E-ekerrizazko & e $z$ kerrikazko & $s$-rekin idazten da \\
\hline
\end{tabular}

Esku-hartze proposamenari dagokionez, digrafoen kasuan, haurrari erakutsi behar zaizkio antzera idazten diren hitzen zerrendak (adibidez, txakurra, txokoa eta etxea) eta begiratu behar da beste hitz batzuetan ' $r$ ' bat beharrean bi jartzen dituen (*urrdin, *karrga, 
esaterako). Aldiz, arauak pixkanaka ikasiz joan behar dira (adibidez, 'hamar' zenbakitik datozen hitzak ' $h$ ' letrarekin idazten dira: hamabi, hamalau, besteak beste; kontsonante biren erdian ' $r$ ' bakarra jartzen da: urdaila, arpa, esaterako).

\section{6. Letrak erregularrak dira?}

Letren tamainaren irregulartasunak aztertzea komeni da (9. taula). Letrek hiru alde izaten dituzte: goiko aldea (d letraren makila adibidez), erdialdea (bokaleak, $c, m, n, \tilde{n}, r, s, v$, $w, x, z$ eta $d, g$ letren borobilak adibidez) eta beheko aldea (j,g adibidez) (Ibarra, 2009b). Irregulartasunak egon daitezke alde horietako bakoitzean. Honela, goiko aldeak edota beheko aldeak oso laburrak edo oso luzeak izan daitezke edota erdialdea tamaina desberdinekoa.

9. taula. Letren tamaina.

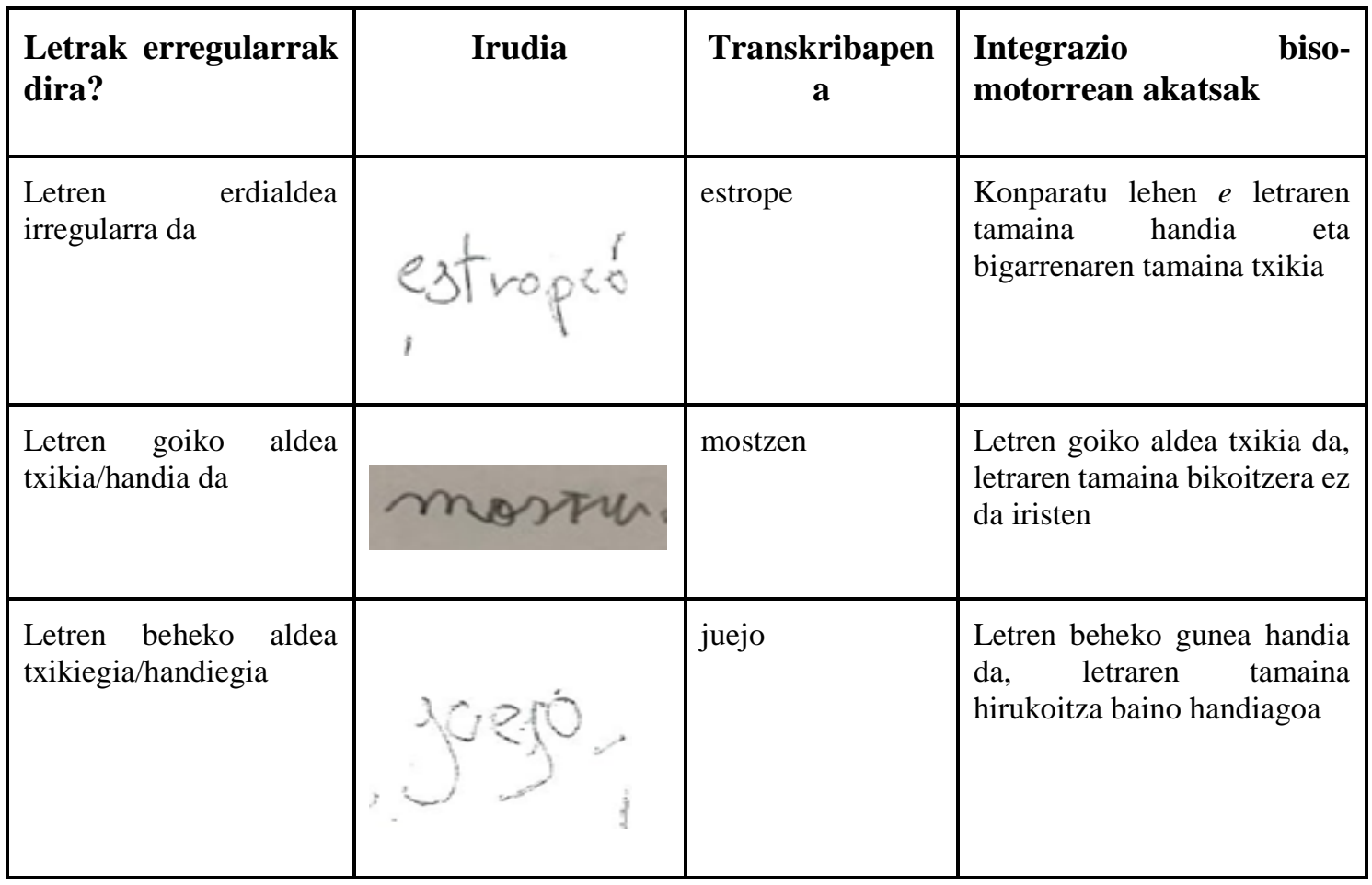

Esku-hartze proposamenari dagokionez, lehenik erdialdea begiratu behar da eta erregularra den ikusi. Horretarako, idatziak duen letrarik txikiena eta handiena neurtzea komeni da; ondoren, irregularra bada, bi lerrotako txantiloiak eman, txantiloi handienetik hasita, eta galdetu zeinetan dagoen eroso. Praktikatu aukeratutakoan 2 astez. Egunean 10 minutu (ikus txantiloiak Ibarra, 2009b). Erdialdea landu ondoren, begiratu beste bi aldeak nola dauden, hau da, erdiko aldearen bikoitzak diren. Beharra badago, alde bakoitza bi 
astetan landu, egunean 10 minutuz. Goiko aldea lantzeko $d, b$ eta $l$ letrak dituzten hitzak eman: adb. alaba. Beheko aldea lantzeko $j, g$ letrak dituzten hitzak eman, adibidez jaia.

\subsection{Hitzen arteko espazioak erregularrak dira?}

Hitzen tarteetan dauden distantziak aztertzea komeni da (10. taula). Erregularrak direnean idazlearen $m$ baten edo bi $o$ letren zabalera izaten dute (Ibarra, 2009b).

10. taula. Hitzen arteko espazioa.

\begin{tabular}{|l|l|l|l|}
\hline $\begin{array}{l}\text { Hitzen arteko } \\
\text { espazioak } \\
\text { erregularrak dira }\end{array}$ & \multicolumn{1}{|c|}{ Irudia } & Transkribapena & $\begin{array}{l}\text { Integrazio biso-motorrean } \\
\text { akatsak }\end{array}$ \\
\hline Tarte estuegia & Etrean febettumulev & $\begin{array}{l}\text { etxean jolastu } \\
\text { nulav }\end{array}$ & $\begin{array}{l}\text { Tarteak estuak dira }(m \text { letra } \\
\text { baino estuagoak) }\end{array}$ \\
\hline Tarteak zabalegia & nuen Eta Am & $\begin{array}{l}\text { "nuen Eta" hitzen arteko } \\
\text { tarteak zabalegiak dira (m } \\
\text { letra baino zabalagoak } \\
\text { baitira) Am }\end{array}$ \\
\hline
\end{tabular}

Esku-hartze proposamenari dagokionez, jarraian dagoen grafismoa egiteak onurak dakartza. Grafismo hau $e$ letrarekin egina dago: $e$ letra hiru-lauko multzoetan egin eta multzo batetik bestera bi $e$ letra uztea komeni da (ikus 1 irudia).

1. irudia. $e$ letrarekin egindako grafismoa.

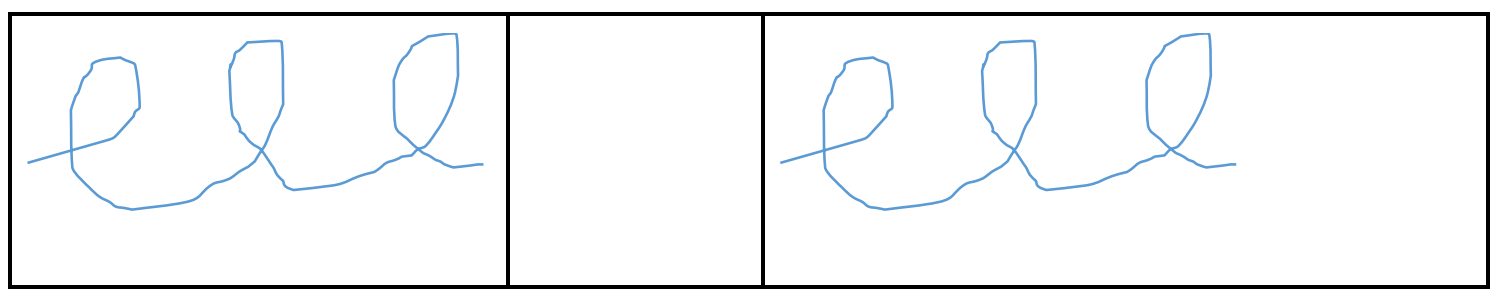

\subsection{Letren arteko loturak ulergarri daude?}

Loturak sailkatu egin daitezke eta sailkapen horien arabera landu (11. taula). Ibarra et al.en (2020b) argitalpenean letren familien arabera loturak sailkatu egin dira: letren aurretik egiten diren loturak batetik eta letren atzetik egiten diren loturak bestetik. Era berean, atzetik egiten diren loturen artean hiru lotura-mota gainbegiratzea proposatzen da: lotura diagonalak, lotura horizontalak eta digrafoekin eginiko loturak. Jarraian ikusgai lotura hauek argi ulertzeko irudia (ikus 2.irudia). 
11. taula. Letren arteko loturen ulergarritasuna. Adibideak eta azalpenak.

\begin{tabular}{|c|c|c|c|}
\hline $\begin{array}{lr}\text { Letren } & \text { arteko } \\
\text { loturak } & \text { ulergarriak } \\
\text { dira? } & \end{array}$ & Irudia & $\begin{array}{c}\text { Transkribape } \\
\text { na }\end{array}$ & Motizitate finan akatsak \\
\hline $\begin{array}{l}\text { Lotura diagonalak } \\
\text { ulergarriak }(e, l, f, i, u)\end{array}$ & & er & $\begin{array}{l}e \text { eta } r \text { letren arteko lotura } \\
\text { diagonala ez da ulergarria }\end{array}$ \\
\hline Lotura horizontalak & & ibili & $\begin{array}{l}b \text { letraren eta } i \text { letraren arteko } \\
\text { lotura horizontala ez da } \\
\text { ulergarria }\end{array}$ \\
\hline $\begin{array}{l}\text { Digrafoak dituzten } \\
\text { loturak }(t x, t z, t s, t t)\end{array}$ & & tx & $\begin{array}{l}t x \text { lotzerakoan lotura 'faltsua' } \\
\text { egin du }\end{array}$ \\
\hline
\end{tabular}

2. irudia. Lotura diagonalak eta horizontalak (kolore lilaz markatuta) (Ibarra et al., 2020b).

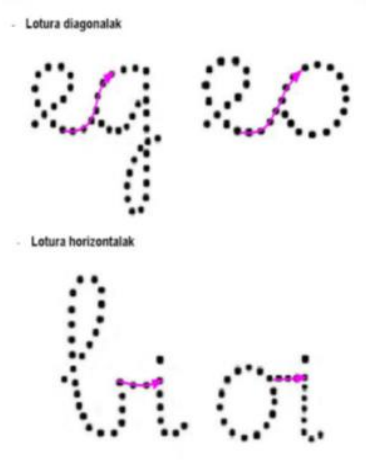

Esku-hartze proposamenari dagokionez, esku-hartzea, letren atzetik egiten diren loturak hobetzetik etorriko da. Behin identifikatuta zein diren ulergarriak ez diren loturak, eskuhartzea, lotura diagonaletan, horizontaletan edota digrafoetan landu beharko da. Horretarako, erabili argitalpenean dauden gezidun irudiak (Ibarra et al, 2020b). 


\subsection{Erritmo/abiadura onean idazten du?}

Erritmo edo abiadura ona izatea garrantzitsua da. 'Kopia azkarraren proba' eginez gero (Ibarra et al., 2017), LHko 2., 4. eta 6. mailen batezbestekoekin konparatu daiteke emaitza. LH2 mailan, 10 hitz/2 minutuko izan zen batezbestekoa, LH4n 22 hitz/2 minutuko eta LH6n 27 hitz/2 minutuko (12. taula).

12. taula. Letrak idazteko abiadura.

\begin{tabular}{|c|l|l|}
\hline Irudia & Transkribapena & Integrazio biso-motorrean akatsak \\
\hline Amaiak Elon homdia zonde & $\begin{array}{l}\text { Amaiak flan handia } \\
\text { janda ospatu zuen } \\
\text { bere egun. }\end{array}$ & $\begin{array}{l}\text { "Kopia azkarraren proban" LH2. mailan 8 } \\
\text { hitz (hauetatik 6 ulergarri) idatzi ditu } \\
\text { ikasle honek 2 minututan. Kopurua batez } \\
\text { bestekoa baino baxuagoa da. }\end{array}$ \\
\hline
\end{tabular}

Esku-hartze proposamenari dagokionez, norbere izena eta zenbakiak idatzi daitezke (10 arte), baita esaldi laburrak ere, egunean 3-4 minutuz. Erronka jarri, hurrengo egunean azkarrago idazteko.

\subsection{Eroso idazten du?}

Eskua-orria eroso egotea oso garrantzitsua da. Elementu horiek txiki-txikitatik gainbegiratzea komeni bada ere, idazkera-zailtasunak hobetzeko, aproposena ez da elementu hauen posizioa aldatzea (13. taula).

Soilik denbora eta motibazioa dagoenean egingo da elementu hauen aldaketa. Gogoratu, eskuaren posizioa aldatzeak ez dakarrela letra hobetzea, guztiz kontrakoa baizik. Eskuaren posizioa aldatzen bada, horrek dakarren trantsiziozko letra-aldaketa baldarra onartu behar da. 
13. taula. Idazkailua eta orria jartzeko modua.

\begin{tabular}{|c|c|c|c|}
\hline Eroso idazten du & Irudia & Azalpena & $\begin{array}{l}\text { Integrazio biso-motorrean } \\
\text { akatsak }\end{array}$ \\
\hline $\begin{array}{l}\text { Orria ez du behar bezala } \\
\text { jartzen }\end{array}$ & $\begin{array}{l}\text { Freepik.com-etik irudia } \\
\text { hartutako illabur.eus/uSuzh } \\
\text { https://labur }\end{array}$ & $\begin{array}{l}\text { Orria bertikal } \\
\text { dauka }\end{array}$ & $\begin{array}{l}\text { Orria apur bat okertzea komeni } \\
\text { da, 6-7 urte ingurutik aurrera. } \\
\text { Ezkertiek pixkat gehiago } \\
\text { okertuz gero erosoago idazten } \\
\text { dute. }\end{array}$ \\
\hline $\begin{array}{l}\text { Idaztresnari ezeroso } \\
\text { heltzen dio }\end{array}$ & $\begin{array}{l}\text { Freepik.com-etik irudia } \\
\text { hartutako https://labur.eus/w3wL } \\
\underline{3}\end{array}$ & $\begin{array}{l}\text { Erpurua } \\
\text { Idaztresnaren } \\
\text { gainean dago }\end{array}$ & $\begin{array}{l}\text { Erpurua erdiko atzamarraren } \\
\text { paralelo egotea komeniko } \\
\text { litzateke }\end{array}$ \\
\hline
\end{tabular}

Esku-hartze proposamenari dagokionez, 'Gustura idatziz' liburuan eta bideoan dituzue argibideak (Ibarra, 2000). Argitalpenean azaltzen den bezala, garrantzitsua da hiru atzamarrek idazkailua eroso heltzea, hasieratik orria eustea, LH 2. mailatik aurrera papera pixka bat okertuta jartzea (ezkertien kasuan okertuago), mahaia ukondoen parean egotea, idazten den eskuko ukondoa mahaiaren gainean pausatuta egotea eta hankak lurrean pausatzea.

\section{Eztabaida eta ondorioak}

Artikulu honen bidez egiaztapen-zerrenda bat proposatu dugu, Lehen Hezkuntzan zehar idazkera-zailtasunak ikasleen artean identifikatzen hasteko. Ikuspegi kognitiboan, Berninger eta lankideen ereduetan zentratuta eta Response to intervention ikuspuntua kontuan hartuz, Tierl mailarako baliabide bat eskaintzen da. Hain zuzen ere, kodetze ortografikoan, kodetze morfologikoan, integrazio ortografiko-motorean eta integrazio biso-motorrean egon daitezkeen zailtasunak identifikatzeko balio dezake. Egiaztapenzerrenda azaltzeko, ikasleen lagin errealak erakusten ditugu, eskola bateko formakuntza- 
saioetatik hartutakoak. Bestalde, egiaztapen-zerrenda horrekin akatsen bat detektatuz gero, esku hartzeko zenbait estrategia eta argitalpen aholkatzen ditugu.

Egiaztapen-zerrenda honen indargune bat, euskaraz, idazketan eta LHn zentratuz, baliabide bat eskaintzea da, momentuz guk dakigunez, ez dagoena. Euskarazko proba eta esku-hartze estandarizatuak iritsi bitartean lagungarria izan daitekeela pentsatzen dugu. Aldiz, ahulezia bat da egiaztapen-zerrendak fidagarritasunik eta balioztapenik ez izatea. Hots, proposamen hau eskola baten formakuntza-saioetan eskaini den arren eta artikulu honetan erakusten den arren, ez dugu ondoren jarraipena egin eta emaitzak ikusi, iradokizunak jaso, e.a.

Etorkizunerako baditugu pentsatuta lerro batzuk:

- Coronado-Hijónek (2015) adierazi bezala, proposaturiko egiaztapen-zerrendaren balioztapena egiteko asmoa dugu.

- Kodetze ortografikoa eta morfologikoa ebaluatzeko eta esku hartzeko baliabideak garatu nahi ditugu.

- Printzipio alfabetikoa sustatzeko hitz-zerrendak prestatu nahi ditugu.

- Azterketa longitudinalak egiteko asmoa ere badugu, hezitzaileen esku jartzeko item bakoitzaren mozketa-puntuak eta baita esku hartzeko baliabideak.

Bagabiltza baita HandSpy sistemarekin (Alves et al., 2019) (http://handspy.dcc.fc.up.pt/account/login) egiaztapen-zerrenda honetan agertzen diren itemak kontuan hartuz, idazketa eta bere zailtasunak in vivo aztertzen eta esku-hartzeak burutzen. Emaitzak argitaratzen jarraituko dugu. 


\section{Bibliografia}

Alves, R. A., Leal, J. P. eta Limpo, T. (2019). Using HandSpy to study writing in real time: A comparison between low-and high-quality texts in grade 2. In E. Lindgren eta KPH. Sullivan (Edk.), Observing Writing (50-70). Brill.

Antzaka, A., Martin, C., Caffarra, S., Schlöffel, S., Carreiras, M. eta Lallier, M. (2018). The effect of orthographic depth on letter string processing: the case of visual attention span and rapid automatized naming. Reading and Writing, 31, 583-605.

Apel, K. (2014). A comprehensive definition of morphological awareness: Implications for assessment. Topics in Language Disorders, 34(3), 197-209.

Apel, K., eta Werfel, K. (2014). Using morphological awareness instruction to improve written language skills. Language, Speech, and Hearing Services in Schools, 45, 251-260.

Bender, L. (1946). Visual-Motor Gestalt Test. New York, NY: American Orthopsychiatric Association.

Berninger, V. W. eta Amtmann, D. (2003). Preventing written expression disabilities through early and continuing assessment and intervention for handwriting and/or spelling problems: Research into practice. In H. L. Swanson, K. R. Harris eta S. Graham (Edk.), Handbook of learning disabilities (345-363). The Guilford Press.

Berninger, V.W. eta Graham, S. (1998). Language by hand: A synthesis of a decade of research on handwriting. Handwriting Review, 12, 11-25.

Berninger, V.W. eta Winn, W. (2006). Implications of advancements in brain research and technology for writing development, writing instruction, and educational evolution, In C. MacArthur, S. Graham eta J. Fitzgerald (Edk.), The Handbook of writing research (96-114). New York: Guilford.

Berninger, V. W. eta Swanson, H. L. (2014). Diagnosing and treating specific learning disabilities in reference to the brain's working memory system. In Handbook of learning disabilities (307-325). New York: Guilford.

Berninger, V. W., Abbott, R. D., Nagy, W. eta Carlisle, J. (2010). Growth in phonological, orthographic, and morphological awareness in grades 1 to 6 . Journal of psycholinguistic research, 39, 141-163. 
Berninger, V. W., Raskind, W., Richards, T., Abbott, R. eta Stock, P. (2008). A multidisciplinary approach to understanding developmental dyslexia within working-memory architecture: Genotypes, phenotypes, brain, and instruction. Developmental neuropsychology, 33, 707-744.

Berninger, V. W., Stage, S. A., Smith, D. R. eta Hildebrand, D. (2001). Assessment for reading and writing intervention: A three-tier model for prevention and remediation. In J. J. W. Andrews, D. H. Saklofske, eta H. L. Janzen (Edk.), Handbook of psychoeducational assessment: Ability, achievement, and behavior in children (195-223). San Diego: Academic Press.

Berninger, V. W., Vaughan, K., Abbott, R. D., Brooks, A., Abbott, S. P., Rogan, L. eta Graham, S. (1998). Early intervention for spelling problems: Teaching functional spelling units of varying size with a multiple-connections framework. Journal of Educational Psychology, 90, 587.

Berninger, V.W., Yates, C., Cartwright, A., Rutberg, J., Remy, E. eta Abbott, R. (1992). Lower-level developmental skills in beginning writing. Reading and Writing, 4, 257-280.

Berninger, V.W. (2007). Process assessment of the learner. Diagnostic for reading and writing (PAL-II RW.) San Antonio, TX: The Psychological Corporation.

Berninger, V.W. (2015). Interdisciplinary frameworks for schools: Best professional practices for serving the needs of all students. American Psychological Association; Washington, DC.

Berninger, V.W. eta Wolf, B. J. (2016). Dyslexia, Dysgraphia, OWL LD, and Dyscalculia Lessons from Science and Teaching. Brookes Publishing.

Coronado-Hijón, A. (2015). Construcción de una lista de cotejo (checklist) de dificultades de aprendizaje del cálculo aritmético. Revista española de pedagogía , 91-104.

Dyslexia Help (2020). Eskuragarri: http://dyslexiahelp.umich.edu/professionals/dyslexia-school/morphologicalawareness [Kontsulta eguna: 2020/11/13].

Euskeraren jatorria (2020). Eskuragarri: http://euskerarenjatorria.eus/?p=1561 [Kontsulta eguna: 2020/11/13].

Eusko Jaurlaritza (2010). Jardunbide egokien gidaliburua. Irakasleak eta irakurketaren irakaskuntza. Eskuragarri: https://www.euskadi.eus/contenidos/informacion/dia6/eu_2027/adjuntos/Recurs osParaLaInclusion/ensenanza_lectura_e.pdf [Kontsulta eguna: 2020/11/13]. 
Eusko Jaurlaritza (2018). Euskadiko Irakurketa Plana. Eskuragarri: https://bideoak2.euskadi.eus/2018/01/31/plan_lector/Euskadiko_Irakurketa_Plan a.pdf [Kontsulta eguna: 2020/11/13].

Eusko Jaurlaritza (2020). 'Irakurgunea' webgunea. Eskuragarri: (https://irakurgune.euskadi.eus/eu/kontzientzia-fonologikoa-lantzeko). [Kontsulta eguna: 2020/11/13].

Granados, D.E. eta Torres, P. (2016). Erros de escritura em espanhol em crianças de terceiro grado de educação primaria. Pensam. psicológico [online]. 14 (2), 113124.

Ibarra, I. (2000). Gustura idatziz. Euba: Ibaizabal.

Ibarra, I. (2009a). Idazketaren didaktika. Hik hasi. Xangorin.

Ibarra, I. (2009b). Kaligrafia: pentsatuz eta eginez — UPV/EHU Ikasmaterialak. Eskuragarri: https://ikasmaterialak.ehu.eus/hezkuntza/kaligrafia-pentsatuzeginez [Kontsulta eguna: 2020/11/13].

Ibarra, I. (2016). Esku-idazketa eta testu eleanitzen arteko loturak. (Doktorego-tesia). Universidad del País Vasco/Euskal Herriko Unibertsitatea.

Ibarra, I., Etxague, X., eta Etxeberria, J. (2017). Letren abiadura Lehen Hezkuntzan: euskarazko batezbestekoak ikasmailaren eta generoaren arabera. Gogoa, 16, 323.

Ibarra, I., Ortube, M. eta Iruskieta, M. (2020b). Loturak landuz: idazketa errazeko programa. Booktegi.

Eskuragarri: http://ixa.si.ehu.es/sites/default/files/dokumentuak/13134/Loturak\%20landuz_i barra-ortube-iruskieta.pdf [Kontsulta eguna: 2020/11/13].

Ibarra, I. (2019). Letra automatikoak eskuz idaztearen ebaluazioa eta irakaskuntza neurogarapeneko ereduaren baitan. In Iker Ros Martínez de Lahidalga (Ed.). XXV Jornadas de Investigación en Psicodidáctica- XXV Psikodidaktikako Ikerkuntza Jardunaldiak (100-107). Bilbo: Euskal Herriko Unibertsitatea.

Ibarra, I., eta Bereziartua Etxeberria, G. (2011). Irakurtzen eta idazten ikasteko proposamenak atzo eta gaur. EHUko testubiltegia. Eskuragarri: https://ikasmaterialak.ehu.eus/hezkuntza/idazten-ikastekoproposamenak/idazten-ikasteko-proposamenak.pdf 
Ibarra, I., Ortube, M., eta Muxika, I. (2020a). Letra xeheak, bai!. Booktegi. Eskuragarri: https://booktegi.eus/liburua/204/letra-xeheak-bai-hainbat-egile

Jiménez, J.E. (2017). Writing Disabilities in Spanish-Speaking Children: Introduction to the Special Series. Journal of Learning Disabilities. 50(5):483-490. doi: $10.1177 / 0022219416633126$.

Jiménez, J. E. (2018). Early Grade Writing Assessment: A report on development of an instrument. $\quad$ Eskuragarri: $\quad$ http://ejimenez.webs.ull.es/wpcontent/uploads/EGWA.pdf

Jiménez, J. E., O'Shanahan, I., de la Luz Tabraue, M., Artiles, C., Muñetón, M., Guzmán, R., eta Rojas, E. (2008). Evolución de la escritura de palabras de ortografía arbitraria en lengua española. Psicothema. Vol. 20, 4, 786-794

Jiménez, J.E., Gove, A., Crouch, L. eta Rodríguez, C. (2014). Internal structure and standardized scores of the Spanish adaptation of the EGRA (Early Grade Reading Assessment) for early reading assessment. Psicothema, 26(4), 531-537. https://doi.org/10.7334/psicothema2014.93

Kaiser, M. L., Albaret, J. M. eta Doudin, P. A. (2009). Relationship between visual-motor integration, eye-hand coordination, and quality of handwriting. Journal of Occupational Therapy, Schools, \& Early Intervention, 2(2), 87-95.

Letrekin EKIN (2020). Eskuragarri: https://letrekinekin.blogspot.com/ [Kontsulta eguna: 2020/11/13].

Levine, M. D., Oberklaid, F. eta Meltzer, L. (1981). Developmental output failure: A study of low productivity in school-aged children. Pediatrics, 67, 18-25.

Ministerio de Educación (2021). Plan de Lectura 2017-2020. Eskuragarri: https://fomentodelalectura.culturaydeporte.gob.es/inicio.html

National Center on Improving Literacy (2020). Eskuragarri: https://improvingliteracy.org/brief [Kontsulta eguna: 2020/11/13].

McCardle, P., Miller, B. eta Connelly, V. (2018). Approaches to Improving Writing Research, Instruction, and Performance. Understanding the Needs of Writers across the Lifecourse, 201-215. 
Philippakos, Z. A. eta FitzPatrick, E. (2018). A Proposed Tiered Model of Assessment in Writing Instruction: Supporting All Student-Writers. Insights into Learning Disabilities, 15(2), 149-173.

Romero-Andonegui, A., Tejada, E. eta Garay, U. (2017). Irakurtzeko gaitasuna Haur Hezkuntzan. Teoriatik praktikara. Tantak, 29(2), 99-118.

Salaburu, P. (2015) Euskal hitz ibilienak. En Fernández, B. eta Salaburu, P. (Edk.). Ibon Sarasola, Gorazarre. Homenaje. (613-627). Bilbo: UPV/EHU (Euskara Institutua)

Staats, C., Oakley, G. eta Marais, I. (2019). A legibility scale for early primary handwriting: Authentic task and cognitive load influences. Issues in Educational Research, 29(2), 537-561.

Thoennes, S. A. (2016). Effective writing interventions for students with learning disabilities. Culminating Projects in Special Education. 14. Eskuragarri: https://repository.stcloudstate.edu/sped_etds/14

UZEI (1994). Atzekoz aurrera. Donostia: UZEI arg. 